\title{
Good Corporate Governance Memoderasi Pengaruh Corporate Sosial Responsibility dan Penerapan Green Accounting terhadap Kinerja Keuangan
}

\author{
Ni Made Somo Misutari ${ }^{1}$ \\ Fakultas Ekonomi dan Bisnis \\ Universitas Udayana, Indonesia
}

\author{
Dodik Ariyanto ${ }^{2}$ \\ Fakultas Ekonomi dan Bisnis \\ Universitas Udayana, Indonesia
}

\begin{abstract}
Surel: smisutari@gmail.com
ABSTRAK

Situasi pandemi Covid-19 yang terjadi di Indonesia menyebabkan banyak program-program tanggung jawab sosial yang sudah di rencanakan untuk diadakan di tahun 2020 banyak tertunda. Kondisi ini menuntut perusahaan merancang program CSR yang adaptif dan inovatif guna merespon kebutuhan masyarakat. Tujuan penelitian ini adalah untuk mengetahui pengaruh Corporate Sosial Responsibility (CSR) dan penerapan green accounting terhadap kinerja keuangan perusahaan serta mengetahui peran Good Corporate Governance (GCG) dalam memperkuat pengaruh Corporate Sosial Responsibility terhadap kinerja keuangan perusahaan. Populasi dalam penelitian ini adalah semua perusahaan Peraih Penghargaan Industri Hijau yang Listing di Bursa Efek Indonesia Tahun 2017-2019. Teknik analisis data menggunakan Moderated Regression Analysis (MRA) dengan program IBM SPSS Statistics 20. Hasil penelitian menunjukkan Corporate Sosial Responsibility dan interaksi Corporate Sosial Responsibility dengan Good Corporate Governance berpengaruh positif dan signifikan pada Kinerja keuangan. Penerapan Green accounting tidak berpengaruh signifikan pada Kinerja keuangan. Hasil juga menunjukkan bahwa GCG merupakan tipe moderasi semua (quasi moderasi).
\end{abstract}

Kata Kunci: $\quad$ CSR; Green Accounting; GCG; Kinerja Keuangan.

\section{Good Corporate Governance Moderates the Effect of Corporate} Social Responsibility and the Implementation of Green Accounting on Financial Performance

\section{ABSTRACT}

The Covid-19 pandemic situation in Indonesia has caused many social responsibility programs that have been planned to be held in 2020 to be delayed. This condition requires companies to design adaptive and innovative CSR prog rams to respond to the needs of the community. Thepurpose of this research is to determine the influence of Corporate Social Responsibility (CSR) and the application of green accounting on the company's financial performance and to know the role of Good Corporate Governance (GCG) in strengthening the influence of Corporate Social Responsibility on the company's financial performance. The population in this study are all Green Industry Award-Winning companies listed on the Indonesia Stock Exchange year 2017-2019. The data analysis technique used Moderated Regression Analysis (MRA) with the IBM SPSS Statistics 20 program. The results showed that Corporate Social Responsibility and the interaction of Corporate Social Responsibility with Good Corporate Governance had a positive and significant effect on financial performance. The application of Green accounting has no significant effect on financial performance. The results also show that GCG is a type of all moderation (quasi moderation).

Keywords: $\quad$ CSR; Green Accounting; GCG; Financial Performance.

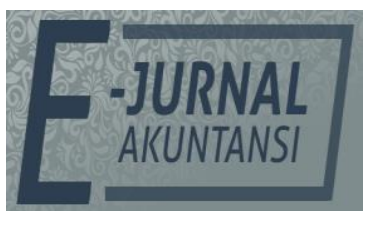

e-ISSN 2302-8556

Vol. 31 No. 12

Denpasar, Desember 2021

Hal. 2975-2987

DOI:

10.24843/EJA.2021.v31.i12.p03

PENGUTIPAN: Misutari, N. M. S. \& Ariyanto, D. (2021). Good Corporate Governance

Memoderasi Pengaruh Corporate Sosial Responsibility dan Penerapan Green Accounting terhadap Kinerja Keuangan. E-Jurnal Akuntansi, 31(12), 2975-2987

RIWAYAT ARTIKEL:

Artikel Masuk: 11 Februari 2021 Artikel Diterima: 2 April 2021

Artikel dapat diakses: https:/ /ojs.unud.ac.id/index.php/Akuntansi/index 


\section{PENDAHULUAN}

Pandemi Covid-19 menuntut perusahaan merancang program CSR yang adaptif dan inovatif guna merespons kebutuhan masyarakat. Disamping itu, perusahaan tetap dituntut menerapkan praktek tanggung jawab sosial dan green accounting dan tetap mempertahankan kinerja keuangan perusahaan baik dalam jangka pendek maupun jangka panjang. Praktek GCG berdasarkan aspek-aspek yang terkandung dalam sustainability reporting perusahaan dapat memperkuat kinerja perusahaan di tengah pandemi Covid-19.

Menurut Parengkuan (2017), Corporate Sosial Responsibility (CSR) atau pertanggung-jawaban sosial perusahaan adalah mekanisme bagi suatu organisasi untuk secara sukarela mengintegrasikan perhatian terhadap lingkungan dan sosial ke dalam operasinya dan interaksinya dengan stakeholders, yang melebihi tanggung jawab organisasi di bidang hukum. CSR merupakan komitmen perusahaan atau dunia bisnis untuk kontribusi dalam pembangunan ekonomi yang berkelanjutan dengan menitik beratkan pada keseimbangan antara perhatian terhadap aspek ekonomi, sosial, dan lingkungan. Penelitian terdahulu mengenai CSR menyatakan bahwa aktivitas tanggung jawab sosial perusahaan memiliki hubungan langsung (direct relationship) dengan kinerja keuangan perusahaan. Perusahaan dengan tingkat kepekaan tinggi terhadap tanggung jawab sosial pasti memiliki kinerja keuangan lebih baik (Garriga \& Mele, 2004). Kinerja keuangan dalam penelitian ini menggunakan proksi Return On Equity (ROE).

Penelitian yang dilakukan oleh Suciwati et al (2016) menyatakan bahwa kinerja keuangan dengan proksi ROE dapat dipengaruhi secara signifikan oleh CSR. Pada penelitian Aliah et al (2020) ditemukannya hasil penelitian yaitu CSR tidak memiliki pengaruh yang signifikan terhadap kinerja keuangan. Penelitian oleh (Prasetyo \& Meiranto, 2017) menemukan hasil bahwa pengungkapan CSR berpengaruh positif terhadap kinerja keuangan. Hasil penelitian terdahulu yang tidak konsisten menyebabkan pengaruh CSR terhadap kinerja keuangan menarik untuk diteliti.

Selain perusahaan wajib menyampaikan informasi CSR dalam laporan tahunannya, perusahaan kini diarahkan untuk menerapkan prinsip industri hijau, akibat kondisi saat ini yang menunjukkan banyaknya kerusakan alam dan semakin menipisnya sumber daya alam yang akan mengancam keberlangsungan kehidupan manusia pada masa yang akan datang, sehingga masyarakat mulai sadar akan pentingnya melestarikan lingkungan. Hal tersebut menyebabkan setiap individu maupun perusahaan dituntut untuk selalu menjaga lingkungan, begitu pula dengan industri merupakan kelompok yang paling besar menyebabkan kerusakan lingkungan. Praktek industri yang ramah lingkungan diimplementasikan melalui penerapan eco-efisiensi dalam praktek manajemen atau green accounting dalam praktek akuntansi (Prasetyo \& Meiranto, 2017)

Penelitian (Puspitasari, 2017), membuktikan bahwa penerapan green accounting berpengaruh positif signifikan terhadap kinerja perusahaan. Semakin tinggi perusahaan menerapkan green accounting maka semakin tinggi pula kinerja perusahaan dan begitu sebaliknya. Hasil serupa dalam penelitian (Sunarmin, 2020) menyatakan bahwa penerapan tek nologi green accounting yang konsisten ternyata mempunyai efek positif terhadap peningkatan kinerja. Namun hasil berbeda diperoleh dalam penelitian Sulistiawati \& Dirgantari (2016) yang 
menyatakan bahwa pengungkapan akuntansi lingkungan tidak berpengaruh terhadap kinerja perusahaan yang diukur dengan kinerja keuangan. Sedangkan dalam penelitian (Putri et al., 2019) yang menemukan hasil bahwa green accounting berdampak signifikansi pada kinerja keuangan perusahaan.

Adanya inkonsistensi hasil penelitian maka perlu dilakukan penelitian kembali mengenai Green accounting dan Corporate Sosial Responsibility dalam mempengaruhi kinerja keuangan. Farhan et al (2019) menjelaskan bahwa agar dapat merekonsiliasi hasil yang bertentangan diperlukan pendekatan kontigensi untuk mengidentifikasi variabel lain yang bertindak sebagai variabel pemoderasi. Teori kontingensi juga dikenal orang sebagai teori situasional. Pendekatan kontingensi (contingency approach) menegaskan bahwa adanya kemungkinan variabel-variabel lain yang bertindak sebagai faktor moderasi yang memperkuat atau memperlemah hubungan antara variabel independen dengan variabel dependen (Yasa \& Sari, 2019). Dalam penelitian ini, variabel yang digunakan sebagai pemoderasi adalah Good Corporate Governance (GCG).

Berdasarkan penelitian Hardiningsih (2018) Corporate governance terbukti sebagai variabel moderasi yang memperkuat pengaruh Corporate Environmental Responsibility terhadap kinerja keuangan. Penelitian serupa oleh Puspitasari (2017), serta (Karina \& Setiadi, 2020) menyatakan bahwa GCG sebagai variabel moderasi memperlemah terhadap hubungan antara CSR dan kinerja keuangan. Hasil moderasi yang tidak konsisten menyebab variable GCG menarik untuk diteliti perannya sebagai variabel moderasi.

Teori utama (grand theory) yang digunakan dalam penelitian ini adalah Teori Sinyal (Signalling Theory). Teori ini menyatakan bahwa perusahaan yang berkualitas baik dengan sengaja akan memberikan sinyal pada pasar dengan demikian pasar diharapkan dapat membedakan perusahaan yang berkualitas baik dan buruk. Berdasarkan kajian pustaka dan uraian-uraian yang telah dipaparkan, kerangka konseptual penelitian ini disajikan dalam Gambar 1. berikut.

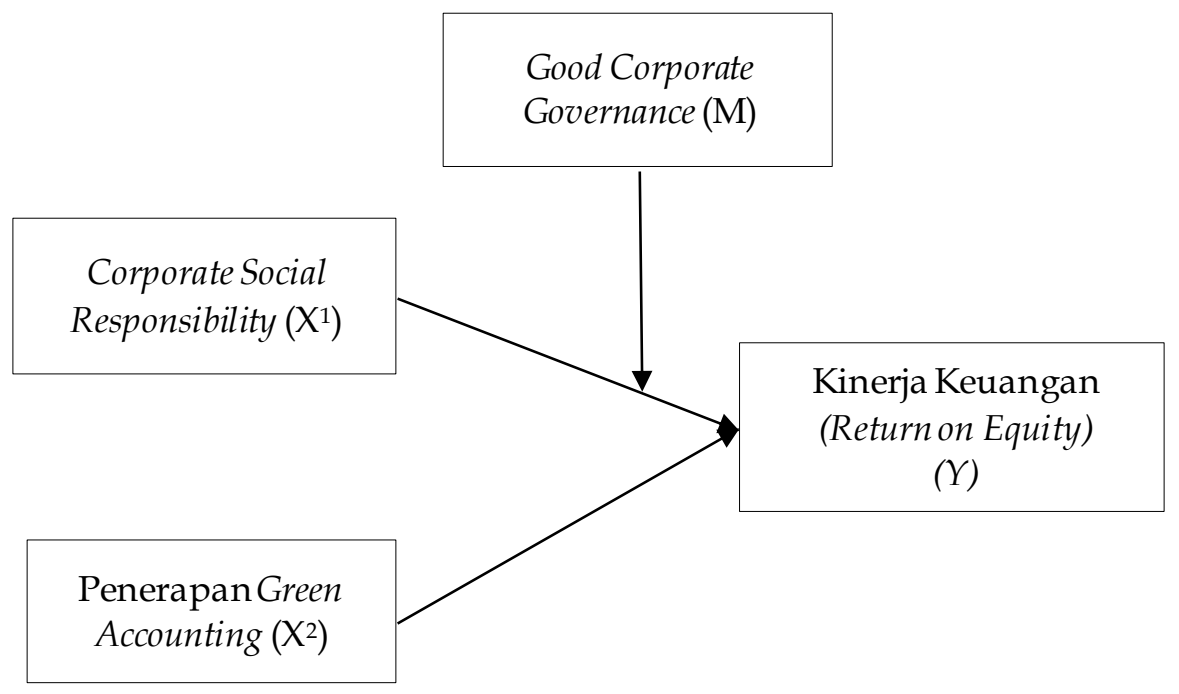

Gambar 1. Kerangka Konseptual

Sumber: Data Penelitian, 2020 
Penelitian yang dilakukan oleh (Tanod et al., 2019) dan (Rodriguez \& Arias, 2016) menunjukkan bahwa Corporate Sosial Responsibility memiliki pengaruh yang signifikan kepada kinerja keuangan perusahaan diukur dengan menggunakan rasio Return On Equity. Penelitian yang dilakukan oleh (Suciwati et al., 2016), (Mariyantini \& Putri, 2018) dan (Prasetyo \& Meiranto, 2017) menemukan hasil Corporate Sosial Responsibility (CSR) memiliki pengaruh positif terhadap kinerja keuangan. Semakin banyak aktivitas Corporate Sosial Responsibility perusahaan yang dilaporkan akan semakin baik dimata investor maupun calon investor, pengungkapan Corporate Sosial Responsibility dapat menunjukan bahwa suatu perusahaan tersebut bertanggung jawab baik terhadap peraturan yang berlaku, masyarakat sekitar maupun lingkungan alam. Teori sinyal juga mengungkapkan bagaimana sinyal keberhasilan dan kegagalan diungkapkan kepada pemilik perusahaan. Berdasarkan teori sinyal, semakin banyak berita bagus (good news) dalam pelaporan terhadap laba dan kegiatan CSR maka semakin baik prospek kinerja perusahaan di masa depan karena perusahaan tidak hanya berfokus pada keuntungan semata namun juga peduli pada hubungan sosial dan kelestarian lingkungan.

$\mathrm{H}_{1}$ : CSR Berpengaruh Positif Terhadap Kinerja Keuangan.

Penelitian (Puspitasari, 2017), (Hamidi, 2019) dan (Sunarmin, 2020) membuktikan bahwa penerapan green accounting berpengaruh positif signifikan terhadap kinerja perusahaan. Semakin tinggi perusahaan menerapkan green accounting maka semakin tinggi pula kinerja perusahaan dan begitu sebaliknya. Hasil serupa dalam penelitian (Putri et al., 2019) dan (Nia, 2020) menemukan bahwa green accounting berdampak signifikansi pada Kinerja keuangan Perusahaan. Hal ini sesuai dengan teori kinerja lingkungan yang mengatakan Jika kinerja lingkungan perusahaan baik, maka image perusahaan akan meningkat.Penerapan green accounting pada perusahaan dapat meningkatkan kinerja lingkungan perusahaan yang berakhir pada peningkatan kinerja keuangan.

$\mathrm{H}_{2}$ : Green Accounting Berpengaruh Positif Terhadap Kinerja Keuangan.

Penelitian (Sirait et al., 2017) serta (Hardiningsih, P., 2018) menemukan bahwa Good Corporate Governance (GCG) dapat memperkuat pengaruh Corporate Sosial Responsibility Terhadap Kinerja keuangan. Hal ini sejalan dengan penelitian yang dilakukan oleh (Utomo, 2016), serta (Naek \& Tjun, 2020) yang menemukan bahwa Good Corporate Governance (GCG) memperkuat pengaruh Corporate Sosial Responsibility terhadap kinerja keuangan. Penilaian GCG dengan governance system dapat memberi sinyal bahwa kinerja perusahaan berjalan optimal dengan kontrol yang memadai. Hal ini sesuai dengan teori sinyal yang mengatakan penilaian ini akan memberikan sinyal positif bagi investor sehingga investor berani untuk menanamkan modalnya yang akan berdampak pada peningkatan harga saham.

$\mathrm{H}_{3}$ : Good Corporate Governance (GCG) Memperkuat Pengaruh Pengungkapan Corporate Sosial Responsibility Terhadap Kinerja Keuangan. 


\section{METODE PENELITIAN}

Penelitian ini menggunakan data kuantitatif, yaitu data annual report perusahaan Peraih Penghargaan Industri Hijau yang Listing di Bursa Efek Indonesia Tahun 2017-2019 serta data lain yang berkaitan dengan variabel penelitian. Populasi penelitian ini adalah seluruh perusahaan Peraih Penghargaan Industri Hijau yang Listing di Bursa Efek Indonesia Tahun 2017-2019. Dari populasi yang ada, diambil beberapa sampel dengan teknik purposive sampling. Setelah data sampel terkumpul, kemudian dilakukan analisis data berdasarkan rumusan hipotesis yang dibuat.

Teknik analisis yang dilakukan dalam proses analisis data adalah Moderated Regression Analysis (MRA). Sebelum melakukan analisis regresi moderasi, dilakukan terlebih dahulu Uji Asumsi Klasik dan analisis faktor untuk mengetahui diantara mekanisme Good Corporate Governance (GCG), mekanisme mana yang akan terpilih untuk digunakan sebagai wakil dari GCG. Analisis faktor digunakan untuk mendefinisikan struktur suatu data matrik dan menganalisis struktur saling hubungan (korelasi) antar sejumlah besar variabel dengan cara mendefinisikan satu kesamaan variabel atau dimensi dan sering disebut dengan factor. Analisis ini berfungsi untuk menemukan suatu cara meringkas informasi yang ada dalam variabel awal menjadi satu set dimensi baru atau variate (factor). Faktor yang akan digunakan diambil dari hasil uji KMO yang memiliki nilai loading faktor paling tinggi dan memiliki nilai MSA $>0.50$.

\section{HASIL DAN PEMBAHASAN}

Analisis faktor konfirmatori digunakan untuk mengetahui apakah indikatorindikator tiap variabel dapat mengkonfirmasikan konstruk atau variabel. Jika semua indikator merupakan indikator konstruk maka dengan sendirinya akan mengelompok menjadi satu dengan faktor loading yang tinggi atau lebih besar 0,5 (Ghozali, 2013). Kelayakan model uji faktor untuk masing-masing variabel dapat dilihat dari nilai Measures of Sampling Adequancy (MSA) pada Tabel 1.

Tabel 1. Nilai MSA Pengukuran Good Corporate Governance

\begin{tabular}{llcccc}
\hline \multicolumn{5}{c}{ Anti-image Matrices } \\
\hline Anti-image Correlation & KM & 0,500 & KI & KA & DKI \\
& KI & 0,154 & 0,502 & 0,102 & 0,027 \\
& KA & 0,102 & 0,004 & 0,004 & 0,009 \\
& DKI & 0,027 & 0,009 & 0,015 & 0,015 \\
& & & &
\end{tabular}

a. Measures of Sampling Adequacy(MSA)

Sumber: Data Penelitian, 2021

Nilai MSA variabel kepemilikan manajerial (KM) sebesar 0,500, nilai MSA variabel kepemilikan institusional (KI) sebesar 0,502, nilai MSA variabel komite audit (KA) sebesar 0,5003, dan nilai MSA variabel dewan komisaris independen (DKI) sebesar 0,430. Hal ini berarti nilai loading faktor tertinggi pada indikator GCG adalah komite audit yang memiliki nilai MSA $\geq 0,50$, yakni memiliki nilai paling tinggi dibandingkan indikator GCG lainnya, sehingga indikator komite audit (KA) layak digunakan dalam analisis faktor untuk menentukan Good Corporate Governance (M). 
Tabel 2. Statistik Deskriptif

\begin{tabular}{lccccc}
\hline & $\mathrm{N}$ & Minimum & Maximum & Mean & Std. Deviation \\
\hline Return On Equity & 111 & $-126,364$ & 30,379 & 4,415 & 17,007 \\
Corporate Social & 111 & 0,637 & 0,890 & 0,750 & 0,042 \\
Responsibility & 111 & 0,000 & 10,000 & 0,811 & 0,393 \\
Green Accounting & 111 & 2,000 & 5,000 & 3,018 & 0,301 \\
Good Corporate & 118 Governance(M). & & & &
\end{tabular}

Sumber: Data Penelitian, 2020

Berdasarkan hasil uji statistik deskriptif menunjukkan jumlah $\mathrm{N}$ sebanyak 111, yang menunjukkan terdapat 111 data observasian yang diteliti dalam penelitian ini yaitu yang diperoleh dari 37 perusahaan selama 3 tahun periode penelitian. Variabel kinerja keuangan dalam penelitian ini diukur menggunakan proksi Return On Equity (ROE) yang merupakan rasiountuk mengukur laba bersih sesudah pajak dengan modal. Nilai Return On Equity (ROE) paling rendah (minimum) adalah sebesar -126,364 persen. Hal ini berarti Perusahaan Peraih Penghargaan Industri Hijau yang Listing di Bursa Efek Indonesia Tahun 2017-2019 memiliki nilai kinerja keuangan paling rendah sebesar $-126,364$ persen yaitu terjadi pada perusahaan Saranacentral Bajatama Tbk. (BAJA) selama periode 2018. Retum On Equity (ROE) yang paling tinggi (maksimum) adalah sebesar 30,379. Hal ini berarti Perusahaan Peraih Penghargaan Industri Hijau yang Listing di Bursa Efek Indonesia Tahun 2017-2019 memiliki nilai kinerja keuangan paling tinggi sebesar 30,379 persen yaitu terjadi pada perusahaan Selamat Sempurna Tbk (SMSM) selama periode 2017. Kinerja keuangan memiliki nilai rata-rata sebesar 4,415, dengan nilai standar deviasi sebesar 17,007. Ini berarti bahwa terjadi perbedaan nilai Kinerja keuangan yang diteliti terhadap nilai rata-ratanya sebesar 17,007 persen. Nilai deviasi standar Kinerja keuangan lebih tinggi dibandingkan dengan nilai rata rata, artinya sebaran nilai kinerja keuangan pada perusahaan peraih penghargaan industri hijau yang Listing di Bursa Efek Indonesia Tahun 2017-2019 tidak merata atau perbedaan data satu dengan data yang lainnya tergolong tinggi.

Variabel Corporate Sosial Responsibility dalam penelitian ini menggunakan proksi CSRDI. Nilai Corporate Sosial Responsibility paling rendah (minimum) adalah sebesar 0,637 yang terjadi pada perusahaan Indo Acidatama Tbk (SRSN) selama periode 2017. Hal ini berarti perusahaan SRSN memiliki penerapan CSR yang paling rendah dibandingkan perusahaan lainnya. Corporate Sosial Responsibility yang paling tinggi (maksimum) adalah sebesar 0,890 yang terjadi pada perusahaan Indofood Sukses Makmur Tbk (INDF) selama periode 2019. Hal ini berarti perusahaan INDF memiliki penerapan CSR yang paling tinggi dibandingkan perusahaan lainnya. Corporate Sosial Responsibility memiliki nilai rata-rata sebesar 0,750 dengan nilai standar deviasi sebesar 0,422 . Ini berarti bahwa terjadi perbedaan nilai Corporate Sosial Responsibility yang diteliti terhadap nilai rata-ratanya sebesar 0,422 persen. Nilai deviasi standar Corporate Sosial Responsibility lebih rendah dibandingkan dengan nilai rata rata, artinya sebaran nilai Corporate Sosial Responsibility pada perusahaan peraih penghargaan industri hijau yang Listing di Bursa Efek Indonesia Tahun 2017-2019 sudah merata atau perbedaan data satu dengan data yang lainnya tidak tergolong tinggi. 
Variabel Green accounting dalam penelitian ini diukur menggunakan variabel dummy, yakni perusahaan yang menerapkan salah satu komponen pengelolaan lingkungan, seperti komponen biaya lingkungan hidup, zakat lingkungan, daur ulang produk, dan biaya pengembangan \& penelitian lingkungan maka diberi kode 1 . Perusahaan tidak mempunyai komponen biaya lingkungan maka diberi kode 0 . Nilai Green accounting paling rendah (minimum) adalah sebesar 0,00 yang terjadi pada perusahaan ALDO, BOLT, INDS, YPAS, TSPC, PYFA dan SULI selama periode 2017-2019. Hal ini berarti perusahaan tersebut memiliki penerapan Green accounting yang paling rendah dibandingkan perusahaan lainnya. Green accounting yang paling tinggi (maksimum) adalah sebesar 1,00 yang terjadi pada 30 perusahaan lainnya selama periode 2019 . Hal ini berarti perusahaan tersrbut memiliki penerapan green accounting yang paling tinggi dibandingkan 7 perusahaan lainnya. Green accounting memiliki nilai ratarata sebesar 0,811 dengan nilai standar deviasi sebesar 0,393. Ini berarti bahwa terjadi perbedaan nilai Green accounting yang diteliti terhadap nilai rata-ratanya sebesar 0,393 persen. Nilai deviasi standar Green accounting lebih rendah dibandingkan dengan nilai rata rata, artinya sebaran nilai Green accounting pada perusahaan peraih penghargaan industri hijau yang Listing di Bursa Efek Indonesia Tahun 2017-2019 sudah merata atau perbedaan data satu dengan data yang lainnya tidak tergolong tinggi.

Variabel Good Corporate Governance dalam penelitian ini diukur dari beberapa indikator yang terdiri dari kepemilikan manajerial, kepemilikan institusional, komite audit dan dewan komisaris independen. Pengukuran Good Corporate Governance dalam penelitian menggunakan analisis faktor (component factor analysis). Hasil analisis faktor menunjukkan faktor yang layak untuk menentukan indeks GCG adalah komite audit, sebab indikator komite audit memiliki nilai $\mathrm{MSA} \geq 0.50$ yang paling tinggi dibandingkan indikator kepemilikan manajerial, kepemilikan institusional, dan dewan komisaris independen. Nilai Good Corporate Governance paling rendah (minimum) adalah sebesar 2,0 yang terjadi pada perusahaan Martina Berto Tbk. (MBTO) selama periode 2017-2019 dan Good Corporate Governance yang paling tinggi (maksimum) adalah sebesar 5,0 yang terjadi pada perusahaan Tifico Fiber Indonesia Tbk (TFCO) selama periode 2019. Good Corporate Governance memiliki nilai rata-rata sebesar 3,018, dengan nilai standar deviasi sebesar 0,300. Ini berarti bahwa terjadi perbedaan nilai Good Corporate Governance yang diteliti terhadap nilai rata-ratanya sebesar 0,300 persen. Nilai deviasi standar Good Corporate Governance lebih rendah dibandingkan dengan nilai rata rata, artinya sebaran nilai Good Corporate Governance pada perusahaan peraih penghargaan industri hijau yang Listing di Bursa Efek Indonesia Tahun 2017-2019 sudah merata atau perbedaan data satu dengan data yang lainnya tidak tergolong tinggi.

Berdasarkan hasil analisis regresi moderasi seperti yang disajikan pada Tabel 3, maka persamaan strukturalnya adalah sebagai berikut.

$$
\mathrm{Y}=0,183+0,088 \mathrm{X} 1+0,035 \mathrm{X} 2+0,321 \mathrm{M}+0,701 \mathrm{X}_{1} * \mathrm{M}
$$

Tabel 3, menunjukkan besarnya nilai adjusted $\mathrm{R}$ Square sebesar 0,616 mempunyai arti bahwa sebesar $61,6 \%$ variasi kinerja keuangan pada perusahaan peraih penghargaan industri hijau yang Listing di Bursa Efek Indonesia Tahun 2017-2019 dipengaruhi oleh variasi Corporate Sosial Responsibility (X1), Green 
accounting $\left(\mathrm{X}_{2}\right)$, Good Corporate Governance $(\mathrm{M})$ serta variabel interaksi antara Corporate Sosial Responsibility dan Good Corporate Governance $\left(\mathrm{X}_{1} . \mathrm{M}\right)$, sedangkan sisanya sebesar $38,4 \%$ djelaskan oleh faktor lain yang tidak dimasukkan ke dalam model.

Tabel 3. Hasil Analisis Regresi Moderasi

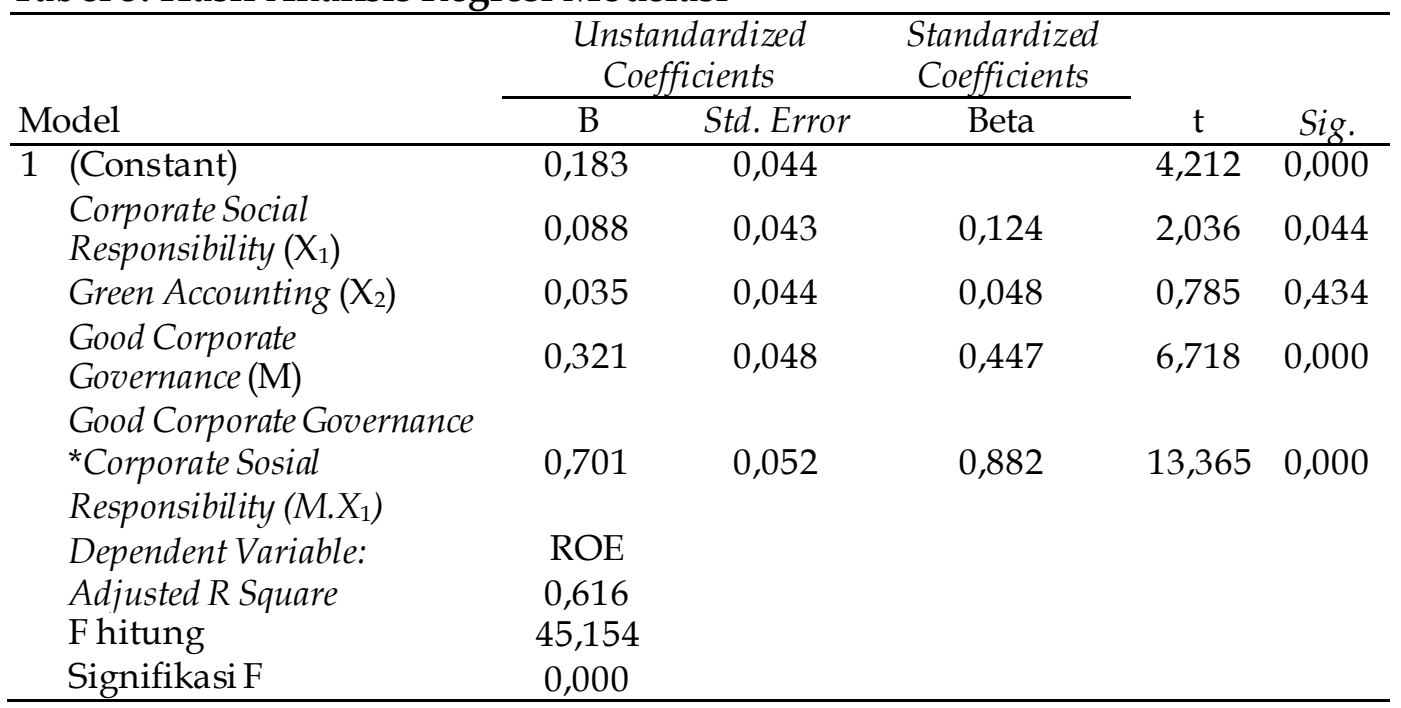

Sumber: Data Penelitian, 2021

Hasil uji F (Ftest) menunjukkan bahwa nilai dengan signifikansi P value 0,000 yang lebih kecil dari $\mathrm{a}=0,05$, ini berarti model yang digunakan dalam penelitian ini adalah layak. Hasil ini memberikan makna bahwa seluruh variabel Corporate Sosial Responsibility $\left(\mathrm{X}_{1}\right)$, Green accounting $\left(\mathrm{X}_{2}\right)$, Good Corporate Governance $(\mathrm{M})$ serta variabel interaksi antara Corporate Sosial Responsibility dan Good Corporate Governance $\left(\mathrm{X}_{1} . \mathrm{M}\right)$ mampu memprediksi atau menjelaskan fenomena kinerja keuangan pada perusahaan peraih penghargaan industri hijau yang Listing di Bursa Efek Indonesia Tahun 2017-2019.

Hipotesis pertama menyatakan bahwa Penerapan Corporate Sosial Responsibility berpengaruh positif dan signifikan pada Kinerja keuangan (ROE). Berdasarkan hasil uji $\mathrm{t}$ analisis regresi pada Tabel 3, memperoleh nilai koefisien regresi Penerapan Corporate Sosial Responsibility sebesar 0,088 dengan tingkat signifikansi sebesar 0,044 yang kurang dari 0,05. Artinya, Penerapan Corporate Sosial Responsibility memiliki pengaruh signifikan (nyata) terhadap Kinerja keuangan (ROE) pada perusahaan peraih penghargaan industri hijau yang Listing di Bursa Efek Indonesia Tahun 2017-2019. Sehingga, dapat disimpulkan bahwa hipotesis pertama diterima.

Hasil penelitian ini menunjukkan bahwa besar kecilnya Penerapan Corporate Sosial Responsibility mampu memengaruhi peningkatan maupun penurunan Kinerja keuangan (ROE). Hal ini menunjukkan semakin tinggi penerapan Corporate Sosial Responsibility maka akan semakin meningkatkan kinerja keuangan (ROE) pada perusahaan peraih penghargaan industri hijau yang Listing di Bursa Efek Indonesia Tahun 2017-2019. Hal ini apabila ditinjau berdasarkan data CSR pada 37 perusahaan yang diteliti, data menunjukkan bahwa sebagian besar perusahaan melaksanakan lebih dari 50\% indikator CSR dari 91 item indeks GRI yang digunakan, sehingga semakin banyak aktivitas Corporate Sosial Responsibility 
perusahaan yang dilaporkan maka akan semakin baik dimata investor maupun calon investor, sebab pengungkapan Corporate Sosial Responsibility dapat menunjukan bahwa suatu perusahaan tersebut bertanggung jawab baik terhadap peraturan yang berlaku, masyarakat sekitar maupun lingkungan alam. Apabila ditinjau berdasarkan kinerja keuangan yang diukur menggunakan rasio ROE, data menunjukkan sebagian besar perusahaan memiliki nilai ROE yang positif, sehingga searah dengan pengungkapan CSR yang dilakukan.

Hasil tersebut mengindikasikan semakin banyak pengungkapan CSR yang dilakukan maka akan meningkatkan minat calon investor untuk berinvestasi pada perusahaan tersebut, semakin banyak calon investor yang berinvestasi pada perusahaan akan meningkatkan harga saham perusahan dan modal yang dimiliki perusahaan juga semakin besar. Modal yang besar tersebut dapat dikelola perusahaan sehingga menghasilkan profit yang tinggi.

Hasil ini sesuai dengan temuan Tanod et al (2019) dan Deni (2018) yang menunjukkan bahwa Corporate Sosial Responsibility memiliki pengaruh yang signifikan kepada kinerja keuangan perusahaan diukur dengan menggunakan rasio Return On Equity. Oleh karena itu, dalam hal ekonomi, ditegaskan bahwa untuk perusahaan ceteris paribus, peningkatkan pengeluaran CSR mengarah pada peningkatan kinerja keuangan, dan lagi pula, perusahaan menikmati kekuatan finansial yang lebih besar jika indeks perilaku sosial meningkat. Ini menghasilkan umpan balik positif yang mendorong perusahaan untuk menerapkan kebijakan CSR dengan sumber daya keuangan mereka, dan membuktikan bagaimana investasi CSR mereka menyebabkan return keuangan meningkat. Hasil ini juga sesuai dengan penelitian Rodriguez \& Arias (2016), Suciwati et al., (2016), Prasetyo \& Meiranto, (2017), Mariyantini \& Putri (2018) yang menemukan hasil bahwa pengungkapan CSR berpengaruh positif terhadap kinerja keuangan.

Hipotesis kedua menyatakan bahwa Green accounting berpengaruh signifikan pada Kinerja keuangan (ROE). Berdasarkan hasil uji $t$ analisis regresi pada Tabel 3, memperoleh nilai koefisien regresi Green accounting sebesar 0,035 dengan tingkat signifikansi sebesar 0,434 yang lebih dari 0,05. Artinya, Green accounting tidak berpengaruh signifikan terhadap Kinerja keuangan (ROE) pada perusahaan peraih penghargaan industri hijau yang Listing di Bursa Efek Indonesia Tahun 2017-2019. Sehingga, dapat disimpulkan bahwa hipotesis kedua ditolak.

Hasil penelitian ini menunjukkan bahwa besar kecilnya Green accounting tidak mampu memengaruhi peningkatan maupun penurunan yang berarti bagi kinerja keuangan (ROE). Hasil penelitian tersebut menunjukkan kondisi perusahaan peraih penghargaan industri hijau yang Listing di Bursa Efek Indonesia Tahun 2017-2019 cukup konservatif dan bersikap hati-hati dalam menerapkan green accounting. Apabila ditinjau berdasarkan data green accounting pada 37 perusahaan yang di teliti dalam penelitian ini menunjukkan bahwa tidak semua perusahaan menerapkan green accounting, dan penerapan Green accounting yang berkaitan dengan informasi lingkungan dan sistem audit lingkungan pada perusahaan peraih penghargaan industri hijau yang Listing di Bursa Efek Indonesia Tahun 2017-2019 belum optimal, sehingga menyebabkan hasil menjadi tidak signifikan. Data juga menunjukkan ada beberapa perusahaan yang menerapkan green accounting, namun memiliki nilai kinerja keuangan yang 
negatif, seperti perusahaan BAJA yang menerapkan green accounting, namun memiliki nilai ROE yang negatif sebesar $-13,36 \%$ dan $-126,36 \%$ pada tahun 2017 2018, sehingga menunjukkan peran utama green accounting untuk mengatasi masalah lingkungan sosial tidak dilaksanakan secara maksimal oleh perusahaan dalam menghadapi isu-isu tanggung jawab sosial dan lingkungan. Hasil ini sesuai dengan temuan Sulistiawati \& Dirgantari (2016) yang menyatakan bahwa pengungkapan akuntansi lingkungan tidak berpengaruh terhadap kinerja perusahaan yang diukur dengan kinerja keuangan. Hasil ini tidak sejalan dengan penelitian Puspitasari (2017), Putri et al., (2019), Sunarmin (2020), dan Nia (2020) yang membuktikan bahwa penerapan green accounting berpengaruh positif signifikan terhadap kinerja perusahaan. Semakin tinggi perusahaan menerapkan green accounting maka semakin tinggi pula kinerja perusahaan dan begitu sebaliknya.

Hipotesis ketiga menyatakan bahwa Good Corporate Governance memoderasi pengaruh Corporate Sosial Responsibility pada Kinerja keuangan (ROE). Berdasarkan hasil uji t analisis regresi pada Tabel 3 menunjukkan koefisien regresi Corporate Sosial Responsibility $\left(\beta_{1}\right)$ positif dan $\beta_{4}$ positif signifikan, yang menunjukkan adanya hubungan searah. Artinya, Good Corporate Governance merupakan variabel moderasi yang memperkuat pengaruh Corporate Sosial Responsibility pada Kinerja keuangan (ROE). Sehingga, dapat disimpulkan bahwa hipotesis ketiga diterima. Apabila ditinjau berdasarkan tipe moderasi, maka penelitian ini termasuk dalam tipe moderasi semu (quasi moderasi). Quasi moderasi adalah jenis variabel moderasi yang dapat diidentifikasi melalui koefisien variabel moderasi $\left(b_{3}\right)$ dan koefisien variabel interaksi $\left(b_{4}\right)$ dalam persamaan regresi pada Tabel 3, yaitu koefisien $b_{3}$ dinyatakan signifikan dengan nilai sebesar 0,000 dan koefisien b4 juga signifikan secara statistik dengan nilai sebesar 0,000, sehingga termasuk jenis moderasi quasi. Quasi moderasi merupakan variabel yang memoderasi hubungan antara variabel prediktor (CSR) dan variabel tergantung (kinerja keuangan) di mana variabel moderasi (GCG) hanya berinteraksi semu, yakni bisa memiliki hubungan yang signifikan dengan variabel prediktor (CSR) sekaligus bisa menjadi variabel prediktor yang mampu berpengaruh langsung pada kinerja keuangan (ROE).

Hasil penelitian ini menunjukkan bahwa apabila interaksi Corporate Sosial Responsibility dengan Good Corporate Governance meningkat, maka akan semakin meningkatkan Kinerja keuangan (ROE) perusahaan peraih penghargaan industri hijau yang Listing di Bursa Efek Indonesia Tahun 2017-2019. Hal ini disebabkan karena CSR merupakan tanggung jawab perusahaan terhadap lingkungan, sehingga pengungkapan CSR dapat memberikan keuntungan tersendiri baik bagi perusahaan maupun stakeholder. Semakin baik pengungkapan informasi yang dilakukan oleh perusahaan maka dapat membuat kinerja keuangan perusahaan yang diukur dengan ROE menjadi meningkat. Tanod et al (2019). Kemudian penerapan CSR yang tinggi diperkuat dengan penerapan GCG yang semakin baik, maka akan semakin mendorong peningkatan pada kinerja keuangan perusahaan. Good Corporate Governance (GCG) sebagai moderasi dapat menciptakan mekanisme dan alat kontrol untuk memungkinkan terciptanya sistem pembagian keuntungan dan kekayaan yang seimbang bagi stakeholders sehingga mampu meningkatkan efisiensi bagi perusahaan dan pada akhirnya dapat menumbuhkan 
kepercayaan investor terhadap perusahaan. Hasil penelitian ini mendukung penelitian Sirait et al (2017) serta Hardiningsih (2018) menemukan bahwa Good Corporate Governance (GCG) dapat memperkuat pengaruh Corporate Sosial Responsibility Terhadap Kinerja keuangan. Hal ini sejalan dengan penelitian yang dilakukan oleh (Utomo, 2016), serta (Naek \& Tjun, 2020) yang menemukan bahwa Good Corporate Governance (GCG) memperkuat pengaruh Corporate Sosial Responsibility terhadap kinerja keuangan.

\section{SIMPULAN}

Simpulan dalam penelitian ini adalah Corporate Sosial Responsibility berpengaruh positif dan signifikan pada Kinerja keuangan (ROE). Hal ini menunjukkan semakin tinggi Penerapan Corporate Sosial Responsibility maka akan semakin meningkatkan Kinerja keuangan (ROE) pada perusahaan peraih penghargaan industri hijau yang Listing di Bursa Efek Indonesia Tahun 2017-2019. Penerapan Green accounting tidak berpengaruh signifikan pada Kinerja keuangan (ROE). Hasil penelitian ini menunjukkan bahwa banyak sedikitnya penerapan Green accounting tidak mampu memengaruhi peningkatan maupun penurunan yang berarti bagi Kinerja keuangan (ROE). Good Corporate Governance mampu memoderasi memperkuat pengaruh Corporate Sosial Responsibility pada Kinerja keuangan (ROE). Hasil penelitian ini menunjukkan bahwa apabila interaksi Corporate Sosial Responsibility dengan Good Corporate Governance meningkat, maka akan semakin meningkatkan kinerja keuangan (ROE) perusahaan. Hasil juga menunjukkan bahwa GCG merupakan tipe moderasi semua (quasi moderasi).

Saran berlandaskan hasil penelitian ini yaitu, Rasio Corporate Sosial Responsibility $\left(\mathrm{X}_{1}\right)$, Good Corporate Governance $(\mathrm{M})$ perlu ditingkatkan karena akan memiliki dampak yang nyata bagi peningkatan kinerja perusahaan, karena kedua variabel tersebut memiliki hubungan yang signifikan terhadap kinerja keuangan perusahaan yang diproksikan dalam rasio ROE. Rasio Green Accounting perlu ditingkatkan karena akan memiliki dampak yang nyata bagi peningkatan kinerja keuangan apabila telah dilakukan secara optimal. Penelitian selanjutnya diharapkan dapat menambah jumlah sampel perusahaan yang akan dijadikan sampel penelitian, misalnya dengan meneliti seluruh perusahaan manufaktur, pertambangan perbankan ataupun perusahaan lainnya yang terdaftar di Bursa Efek Indonesia.

\section{REFERENSI}

Farhan, M., Helmy, H., \& Afriyenti, M. (2019). Pengaruh Machiavellian Dan Love Of Money Terhadap Persepsi Etika Penggelapan Pajak Dengan Religiusitas Sebagai Variabel Moderasi. Jurnal Eksplorasi Akuntansi, 1(1), 470-486.

Fernandez-Rodriguez, E., \& Martinez-Arias, A. (2016). Do Business Characteristics Determine an Effective Tax Rate? 1475(March). https: / / doi.org/10.2753/CES1097-1475450604

Garriga, E., \& Melé, D. (2004). Corporate social responsibility theories: Mapping the territory. Journal of Business Ethics, 53(1-2), 51-71. https:/ / doi.org/10.1023/B:BUSI.0000039399.90587.34

Hamidi. (2019). Analisis Penerapan Green Accounting Terhadap Kinerja Keuangan Perusahaan. Equilibiria, 6(2), 23-36. 
https:/ / www.journal.unrika.ac.id/index.php/ equi/article/view/2253

Hardiningsih, P., Y. (2018). Faktor- Faktoryang Mempengaruhi Kemampuan Membayar Pajak. 3(1), 126-143.

Karina, D. R. M., \& Setiadi, I. (2020). Pengaruh CSR Terhadap Nilai Perusahaan Dengan GCG Sebagai Pemoderasi. 6(1), 37-49.

Mariyantini, N. L. P. N., \& Putri, I. G. A. M. A. D. (2018). Pengaruh CSR dan Intellectual Capital Pada Kinerja Keuangan Perbankan Yang Terdaftar di BEI Periode 2013-2016. E-Jurnal Akuntansi Universitas Udayana, 23(2), 1171-1200.

Naek, T., \& Tjun Tjun, L. (2020). Pengaruh Corporate Social Responsibility Terhadap Kinerja Perusahaan Dengan Good Corporate Governance Sebagai Variabel Moderasi Pada Perusahaan Manufaktur Di Bursa Efek Indonesia Periode 2015-2017. Jurnal Akuntansi Maranatha, 12(1), 123-136. https:/ / doi.org/10.28932/jam.v12i1.2323

Nia, R. (2020). Pengaruh Green Accounting Terhadap Corporate Social Responsibility Disclosure pada Bank Umum Syariah di Indonesia dengan Kinerja Keuangan Sebagai Variabel Intervening (Periode 2015 - 2018). In Osteoarthritis and Cartilage (Vol. 28, Issue 2). Universitas Islam Negeri Raden IntanLampung. http:/ / journals.sagepub.com/ doi/10.1177/1120700020921110\%0Ahttps:/ / doi.org/10.1016/j.reuma.2018.06.001\%0Ahttps:// doi.org/10.1016/j.arth.201 8.03.044\%0Ahttps://reader.elsevier.com/reader/sd/ pii/S106345842030007 8?token $=$ C039B8B13922A2079230DC9AF11A333E295FCD8

Parengkuan, W. E. (2017). Pengaruh Corporate Social Responsibility(Csr) Terhadap Kinerja Keuangan Perusahaan Manufaktur Yang Terdaftar Di Bursa Efek Indonesia Melalui Pojok Bursa Feb - Unsrat. 5(2), 564-571.

Prasetyo, A., \& Meiranto, W. (2017). Pengaruh Corporate Social Responsibility Terhadap Kinerja Keuangan Perusahaanmanufaktur Yang Terdaftar Di Bei Tahun 2013 - 2015. 6, 1-12.

Puspitasari, A. D. (2017). Analisis Pengaruh Enterprise Risk Management Disclosure, Intellectual Capital Disclosure, Dan Corporate Social Responsibility Disclosure Terhadap Nilai Perusahaan (Studi Empiris Pada Perusahaan Pertambangan Yang Terdaftar Di Bei Tahun 2012-2015).

Putri, A. M., Hidayati, N., \& Amin, M. (2019). Dampak Penerapan Green Accounting Dan Kinerja Lingkungan Terhadap Profitabilitas Perusahaan Manufaktur Di Bursa Efek Indonesia. 08(04), 149-164.

Putu, N., Murtining, S., \& Dwiyanti, K. T. (2019). Pengaruh love of money , machiavellian, dan equity sensitivity terhadap persepsi etika penggelapan pajak ( Tax Evasion ) FakultasaEkonomirdan BisnisaUniversitasaPendidikan Nasionalf ( Undiknas ), Bali, Indonesia AB. E-Jurnal Akuntansi Universitas Udayana, 26, 1412-1435.

Sirait, M., Bukit, N., \& Siregar, N. (2017). Preparation and characterization of natural bentonite in to nanoparticles by co-precipitation method. AIP Conference Proceedings, 1801(January). https:// doi.org/10.1063/1.4973084

Suciwati, D. P., Pradnyan, D. P. A., \& Ardina, C. (2016). Pengaruh Corporate Social Responsibility Terhadap Kinerja Keuangan (Pada Perusahaan Sektor Pertambangan di Bei Tahun 2010-2013). Jurnal Bisnis Dan Kewirausahaan, 12(2), 104-113. 
Sulistiawati, E., \& Dirgantari, N. (2016). Analisis Pengaruh Penerapan Green Accounting Terhadap Profitabilitas Pada Perusahaan Pertambangan yang Terdaftar di Bursa Efek Indonesia. 6(1), 865-872.

Sunarmin. (2020). Green Technology Accounting as an Innovation to Reduce Environmental Pollution. 1(2), 135-141.

Tanod, K. N., Nangoi, G. B., \& Suwetja, I. G. (2019). Pengaruh Penerapan Corporate Social Responsibility Terhadap Profitabilitas Perusahaan Manufaktur Di Bursa Efek Indonesia Tahun 2013-2017. 14(1), 101-109.

Utomo, N. A. (2016). Faktor-Faktor Yang Mempengaruhi Nilai Perusahaan Pada Perusahaan Indeks LQ45 Di Bursa Efek Indonesia. 5(1), 82-94. 